Japan. J. Med. Sci. Biol., 21, 275-281, 1968

\title{
SHIGELLOSIS IN CYNOMOLGUS MONKEYS (MACACA IRUS)
}

\author{
VI. THE INOCULATION WITH VARIOUS DOSES OF \\ SHIGELLA FLEXNERI 2a INTO CECAL LUMEN
}

\author{
MASAo TAKASAKA*, SHIgEo HONJO*, TOORU FUJIWARA*, \\ KIYOSHI IMAIZUMI*, HidEMASA OGAWA**, RiNTARO NAKAYA*** \\ AND AKIKO NAKAMURA*** \\ * Department of Veterinary Science, ** Department of Pathology, \\ *** Department of Bacteriology I, National Institute of Health, Tokyo 141, Japan
}

(Received: May 29th, 1968)

\begin{abstract}
SUMMARY : Various doses of a virulent strain of S. flexneri 2a were injected into the cecal lumen of 20 cynomolgus monkeys.

Seven of 8 monkeys inoculated with $10^{9}$ of the bacilli developed pronounced dysentery, 3 of 6 monkeys with $10^{7}$ organisms and 1 of 6 monkeys with $10^{5}$ developed dysentery, respectively. Clinical and pathological findings in these dysenteric cases were essentially the same as those in the oral administration with $10^{9}$ of the bacilli. Thus, the method of direct injection of S. flexneri 2a into the cecal lumen proved useful to produce experimental dysentery even with relatively small doses such as $10^{7}$ or $10^{5}$ bacilli with which the authors could not produce dysentery by the oral route.

The possible mechanisms of the establishment of $S$. flexneri 2a infection in the alimentary tract of the monkeys are discussed from the viewpoint of the inoculum size and the inoculation route.
\end{abstract}

\section{INTRODUCTION}

In the previous studies (Honjo et al., 1964, Ogawa et al., 1964, Takasaka et al., 1967), it has been demonstrated that, when healthy cynomolgus monkeys were administered with $10^{9}-10^{10}$ of a virulent strain of $S$. flexneri 2 a by the oral route, about $50-60 \%$ of the monkeys developed typical dysentery, while the oral infection with $10^{6}$ bacilli could not produce typical clinical signs of dysentery. However, in some monkeys administered orally with $10^{6}$ bacilli, the number of organisms in rectal excreta increased to $10^{7}$ or more after the administration and they have sometimes loose or muddy stools or stools containing a minute quantity of bloody mucus. Though we have no precise information about the number of bacilli necessary for the establishment of infection in naturally occurring dysentery of monkeys and also of human beings, it is suspicious that such a large dose of Shigella as $10^{9}$ is actually taken in those cases. Thus, it has been considered that dysentery might be produced experimentally in monkeys with

高阪 精夫・本庄 重男・藤原 徹・今泉 清 (国立予防衛生研究所獣疫部)

小河 秀正(国立予防衛生研究所病理部)

中谷林太郎・中村 明子 (国立予防衛生研究所細菌第一部)

R. Nakaya (Present Addres: National Institute of Public Health, Tokyo 108, Japan) 
relatively small doses of $S$. Alexneri 2a, if their resistance for Shigella infection is reduced by some adequate pretreatment.

Furthermore, the authors have reported that the large intestine was regarded as the primary site of multiplication of orally administered $S$. flexneri 2a even at the earlier stage of infection, while in the small intestine there was no evidence of a pronounced increase in the number of the bacilli (Ogawa et al., 1966).

In the present study, the authors attempted to determine the smallest dose necessary for the production of experimental dysentery by means of the direct injection with various doses of $S$. Alexneri 2a into cecal lumen, excluding the influence of factors relating to the resistance against Shigella in the upper alimentary tract of cynomolgus monkeys.

\section{MATERIALS AND METHODS}

Animals and infection procedures: Twenty seven cynomolgus monkeys (Macaca irus) weighing from 1.5 to $3.9 \mathrm{~kg}$ were divided into 4 groups.

During the conditioning period of at least 5 weeks at the animal room, stool specimens of each monkey were confirmed to be negative for Shigella bacilli on 3 to 7 occasions. The method of care and management of monkeys was the same as described previously (Takasaka et al., 1964).

Virulent S. Alexneri 2a strain 5503 (Ogawa et al., 1966) grown on nutrient agar plates at $37 \mathrm{C}$ for $18 \mathrm{hr}$ was used.

As shown in Table 1 , group 1 was injected with about $10^{9}$ bacilli suspended in $10 \mathrm{ml}$ of sterile saline, while groups 2 and 3 were injected with about $10^{7}$ and $10^{5}$ organisms, respectively. The monkeys were starved for 24 to $32 \mathrm{hr}$ before the administration of bacilli.

The abdomen anesthetized locally with $2 \%$ procaine hydrochloride was opened through a midline incision and the cecum was exposed. The suspended organisms were injected slowly into the cecal lumen using a syringe fitted with a 23-gauge needle, and then the abdominal incision was closed in the usual manner of abdominal suture.

As controls, 7 monkeys of group 4 were orally administered with about $10^{9}$ bacilli by the same method as described previously (Honjo et al., 1964).

Bacteriological procedures: Isolation of $S$. flexneri 2a from rectal swab was tried on both SS and MacConkey agars. Quantitative culture of rectal excreta for S. flexneri 2a was also carried out on SS agar by the method of Miles, Misra and Irwin (1938).

Titration of humoral antibody against S. flexneri 2a: Blood sera of some animals of groups 1, 2 and 3 were obtained just before the administration of bacilli, and 1 and 2 weeks after the challenge.

Serum agglutinin titers against $S$. flexneri 2a were determined in the same manner as described previously (Honjo et al., 1967).

Histopathological observations: Observations of the microscopic lesions of alimentary tract and of the distribution of $S$. Alexneri 2a in tissue were carried out by the routine histological method and the fluorescent antibody technique described previously (Ogawa et al., 1964).

\section{RESUlts}

As shown in Table 1,7 of 8 monkeys (87.5\%) in group 1, 3 of 6 monkeys (50\%) 
Table 1. Numbers of $S$. flexneri 2a challenged and of dysenteric cases produced

\begin{tabular}{cccc}
\hline Group & $\begin{array}{c}\text { No. of viable } \\
\text { cell given }\end{array}$ & $\begin{array}{c}\text { No. of } \\
\text { animals used }\end{array}$ & $\begin{array}{c}\text { No. of } \\
\text { dysenteric cases }\end{array}$ \\
\hline 1 & $6.2 \times 10^{9}$ & 8 & 7 \\
2 & $5.6 \times 10^{7}$ & 6 & 3 \\
3 & $6.8 \times 10^{5}$ & 6 & 1 \\
4 (Cont.)* & $5.6 \times 10^{9}$ & 7 & $4-5$ \\
\hline
\end{tabular}

* Group 4 (Cont.) was challenged orally with the bacilli.

in group 2 and 1 of 6 monkeys $(16.7 \%)$ in group 3 were dysenteric cases. Four or 5 of 7 orally infected monkeys $(57.1-71.4 \%$ ) of group 4 were dysenteric cases (see footnotes*).

The clinical findings, the gross and microscopic changes of the large intestine and the isolation of Shigella from the large intestine are summarized in Table 2.

Five of 7 dysenteric cases of group 1 began to excrete a large quantity of bloody mucous stool almost regularly 2 days after the injection of bacilli (2.4 days on the average of the 7 cases), 3 dysenteric cases of group 2 developed bloody mucous stool after 2,3 and 8 days, respectively (4.3 days on the average) and in one dysenteric case of group 3 bloody mucous diarrhoea appeared 5 days after the injection. In all dysenteric cases of groups 1,2 and 3 , the number of $S$. flexneri 2a per gram of the dysenteric stool ranged from $10^{7}$ to $10^{8}$ which was of approximately the same order as in the stool of orally infected monkey as shown in the previous studies (Honjo et al., 1964, Takasaka et al., 1967).

Gross and histological findings, including distribution of fluorescing bacilli, in dysenteric cases of groups 1, 2 and 3 were essentially the same as those of group 4 . Namely, erosive lesions, accompanying bacterial invasion into epithelium and sometimes into lamina propria, were widely found in the severe cases of experimental groups. Microabcesses in crypts were also frequently formed in these cases. Fluorescing bacilli were massively demonstrated in them. Inflammatory edema was observed in the mucosa to submucous layers. In moderately affected cases of both the experimental and control groups, bacterial invasion was almost limited to the epithelium of catarrhalic areas with slight exudative change. No. 1 of group 2, on the early stage of infection, showed slight changes, that is, fluorescing bacteria were localized only in several superficial epithelial cells, and inflammatory response was also limited to the areas just under the parasitized epithelia. In No. 4 of group 4 autopsied 12 days after the challenge, microfoci in which a few epithelial cells harbored fluorescing bacteria were observed though gross and inflammatory changes were not clear. No pathologic change was observed in the small intestine.

* From stools of monkey No. 2 of group 4, S. sonnei was isolated immediately before the administration of $S$. flexneri $2 \mathrm{a}$ and 2 days after the administration, and the stool was loose in those days. Four days after the challenge, it developed dysenteric diarrhoea. It is difficult, therefore, to determine strictly whether the development of dysentery was induced by $S$. flexneri 2a administered experimentally or by naturally infected $S$. sonnei. Therefore, in Table 1, the number of dysenteric cases of group 4 is represented as 4 or 5 of 7 monkeys used. 
Table 2. Summary of clinical and pathological changes observed

\begin{tabular}{|c|c|c|c|c|c|c|}
\hline \multirow{2}{*}{ Group } & \multirow{2}{*}{$\begin{array}{c}\text { Animal } \\
\text { No. }\end{array}$} & \multirow{2}{*}{$\begin{array}{l}\text { Appearance of } \\
\text { clinical sign* } \\
\text { (days after } \\
\text { the challenge) }\end{array}$} & \multirow{2}{*}{$\begin{array}{c}\text { Fate** } \\
\text { (days after } \\
\text { the } \\
\text { challenge) }\end{array}$} & \multicolumn{2}{|c|}{ Large-intestinal lesions } & \multirow{2}{*}{$\begin{array}{l}\text { Isolation of } \\
\text { Shigella } \\
\text { from large } \\
\text { intestine**** } \\
\text { (at the time } \\
\text { of autopsy) }\end{array}$} \\
\hline & & & & Intensity & $\begin{array}{c}\text { Bacterial*** } \\
\text { penetration }\end{array}$ & \\
\hline \multirow{8}{*}{1} & 1 & $\mathrm{P}, 2$ days & $\mathrm{D}, 4$ days & Severe & H & + \\
\hline & 2 & $\mathrm{P}, 3$ & $\mathrm{D}, 5$ & Moderate & $H$ & + \\
\hline & 3 & $\mathrm{P}, 2$ & $\mathrm{~S}, 2$ & Severe & & + \\
\hline & 4 & $\mathrm{P}, 2$ & $\mathrm{D}, 4$ & Severe & 世 & + \\
\hline & 5 & $\mathrm{~N}$ & Survived & & & \\
\hline & 6 & $\mathrm{P}, 2$ & $\mathrm{~S}, 2$ & Severe & H & + \\
\hline & 7 & $\mathrm{P}, 2$ & $\mathrm{D}, 5$ & Moderate & & + \\
\hline & 8 & $\mathrm{P}, 4$ & S, 9 & Moderate & & + \\
\hline \multirow{6}{*}{2} & 1 & $\mathrm{P}, 2$ & $\mathrm{D}, 2$ & Slight & + & + \\
\hline & 2 & $\mathrm{~N}$ & $\mathrm{~S}, 7$ & None & - & + \\
\hline & 3 & $\mathrm{~N}$ & Survived & & & \\
\hline & 4 & $\mathrm{P}, 3$ & $\mathrm{~S}, 4$ & Severe & H & + \\
\hline & 5 & $\mathrm{~N}$ & Survived & & & \\
\hline & 6 & $\mathrm{P}, 8$ & Survived & & & \\
\hline \multirow{6}{*}{3} & 1 & $\mathrm{~N}$ & $\mathrm{~S}, 15$ & None & - & + \\
\hline & 2 & $\mathrm{P}, 5$ & $\mathrm{D}, 6$ & Moderate & \pm & + \\
\hline & 3 & $\mathrm{~N}$ & Survived & & & \\
\hline & 4 & $\mathrm{~N}$ & $\mathrm{~S}, 15$ & None & - & + \\
\hline & 5 & $\mathrm{~N}$ & Survived & & & \\
\hline & 6 & $\mathrm{~N}$ & Survived & & & \\
\hline \multirow{7}{*}{$\begin{array}{c}4 \\
\text { (Cont.) }\end{array}$} & 1 & $\mathrm{~N}$ & Survived & & & \\
\hline & 2 & $\mathrm{P}, 4$ & Survived & & & \\
\hline & 3 & $\mathrm{P}, 2$ & $\mathrm{~S}, 2$ & Moderate & + & + \\
\hline & 4 & $\mathrm{P}, 4$ & $\mathrm{~S}, 12$ & Slight & \pm & + \\
\hline & 5 & $\mathrm{P}, 2$ & Survived & & & \\
\hline & 6 & $\mathrm{~N}$ & Survived & & & \\
\hline & 7 & $\mathrm{P}, 1$ & $\mathrm{D}, 3$ & Moderate & & + \\
\hline
\end{tabular}

* P : Positive (bloody mucous stool),

$\mathrm{N}$ : Negative.

** D : Died,

S: Sacrificed.

*** W : Widely penetrated into epithelial lining and lamina propria,

H : Locally penetrated into epithelial lining,

+ : Penetrated into surface epithelium, not into deeper crypt,

\pm : A few epithelial cells harbored $S$. flexneri $2 \mathrm{a}$,

- : No penetration.

$* * * *+: S$. flexneri 2a positive.

Table 3 summarizes results of isolation of $S$. flexneri 2a from various parts of the gastrointestinal tract of the autopsied animals. In dysenteric cases of the experimental groups, S. Alexneri 2a was isolated in number of $10^{5.3}$ to $10^{9.5}$ from various parts of 
Table 3. Isolation of S. flexneri 2a from various parts of the gastrointestinal tract

\begin{tabular}{|c|c|c|c|c|c|c|c|c|}
\hline \multirow{2}{*}{ Group } & \multirow{2}{*}{$\begin{array}{c}\text { Animal } \\
\text { No. }\end{array}$} & \multirow{2}{*}{ Stomach } & \multirow{2}{*}{$\begin{array}{l}\text { Lower } \\
\text { small } \\
\text { intestine }\end{array}$} & \multicolumn{5}{|c|}{ Large intestine } \\
\hline & & & & Cecum & $\begin{array}{l}\text { Ascend- } \\
\text { ing colon }\end{array}$ & $\begin{array}{l}\text { Transverse } \\
\text { colon }\end{array}$ & $\begin{array}{l}\text { Descend- } \\
\text { ing colon }\end{array}$ & Rectum \\
\hline \multirow{7}{*}{1} & $1^{\bullet}(\mathrm{D})$ & & + & + & & + & & \\
\hline & $2^{\bullet}(\mathrm{D})$ & - & + & + & & + & & + \\
\hline & $3^{\bullet}(\mathrm{S})$ & $<3$ & $<3$ & 8.9 & 9.4 & & & 8.5 \\
\hline & $4^{\bullet}(\mathrm{D})$ & - & - & + & & + & & + \\
\hline & $6^{\bullet}(\mathrm{S})$ & $<3$ & $<3$ & 8.4 & & & 8.1 & 7.6 \\
\hline & $7^{\bullet}(\mathrm{D})$ & & + & + & & + & + & \\
\hline & $8^{\bullet}(\mathrm{S})$ & & & + & & + & + & \\
\hline \multirow{3}{*}{2} & $1^{\bullet}(\mathrm{D})$ & & - & + & + & & 9.5 & + \\
\hline & $2(\mathrm{~S})$ & - & - & 4.7 & + & & & + \\
\hline & $4^{\bullet}(\mathrm{S})$ & & 3.7 & 5.3 & 6.7 & + & + & + \\
\hline \multirow{3}{*}{3} & $1(\mathrm{~S})$ & - & - & - & & & 4.3 & \\
\hline & $2 \bullet(D)$ & - & 7.1 & 7.4 & 7.9 & & & 7.8 \\
\hline & $4(\mathrm{~S})$ & - & - & - & & & 2.8 & \\
\hline \multirow{3}{*}{$\begin{array}{c}4 \\
\text { (Cont.) }\end{array}$} & $3^{\bullet}(\mathrm{S})$ & & + & + & + & & & + \\
\hline & $4^{\bullet}(\mathrm{S})$ & + & + & - & + & & & - \\
\hline & $7^{\bullet}(\mathrm{D})$ & & & + & + & & & \\
\hline
\end{tabular}

Notes : 1) Number of isolated S. flexneri 2a per gram of intestinal content is expressed as logarithm to the base of 10 .

2) + : S. flexneri 2a positive, - : S. flexneri 2a negative.

3) Animal No. ${ }^{\bullet}$ Dysenteric case.

4) D: Died, S: Sacrificed.

the large intestine of the animals autopsied 2-6 days after the challenge. In No. 2 of group 3, bacilli were isolated from the lower small intestine as well as from the cecum in about the same number.

As shown in Table 4, in almost all animals of the groups challenged intracecally with $S$. flexneri 2a, serum agglutinin titers had a trend to rise 1-2 weeks after the challenge regardless of the presence or absence of dysentery symptoms and of the challenge doses.

\section{DISCUSSION}

In the present study, the authors produced dysentery in cynomolgus monkeys by means of the direct injection with various doses of a virulent strain of $S$. flexneri $2 \mathrm{a}$ into the cecal lumen. Clinical and pathological findings of the present cases were not distinguishable from either those of dysenteric cases following the oral administration of the bacilli or those of naturally occurring dysentery.

Thus, the present method of direct injection of $S$. Alexneri 2a into the cecal lumen proved useful to produce experimental dysentery with relatively small doses such as $10^{7}$ or $10^{5}$ bacilli. The morbidity rate of dysentery in group $2(50 \%)$ challenged with 
Table 4. Serum agglutinin titers before and after the challenge

\begin{tabular}{|c|c|c|c|c|}
\hline Group & Animal No. & $\begin{array}{l}\text { Before } \\
\text { challenge }\end{array}$ & $\begin{array}{c}1 \text { week } \\
\text { postchallenge }\end{array}$ & $\begin{array}{c}2 \text { weeks } \\
\text { postchallenge }\end{array}$ \\
\hline 1 & $\begin{array}{l}5 \\
8 \bullet\end{array}$ & $\begin{array}{l}3^{*} \\
2\end{array}$ & $\begin{array}{l}4 \\
5\end{array}$ & 5 \\
\hline 2 & $\begin{array}{l}2 \\
3 \\
5 \\
6^{\bullet}\end{array}$ & $\begin{array}{r}<2 \\
3 \\
4 \\
4\end{array}$ & $\begin{array}{l}3 \\
3 \\
5 \\
5\end{array}$ & $\begin{array}{l}3 \\
6 \\
6\end{array}$ \\
\hline 3 & $\begin{array}{l}1 \\
2 \bullet \\
3 \\
4 \\
5 \\
6\end{array}$ & $\begin{array}{r}3 \\
<2 \\
2 \\
2 \\
3 \\
3\end{array}$ & $\begin{array}{l}3 \\
8 \\
5 \\
3 \\
6 \\
5\end{array}$ & $\begin{array}{l}9 \\
5 \\
4 \\
6 \\
5\end{array}$ \\
\hline
\end{tabular}

* Titer is defined by $\mathrm{n}$ in $1: 2^{\mathrm{n}}$ which is serum dilution.

Animal No. ${ }^{\bullet}$ Dysenteric case.

$10^{7}$ organisms was comparable to the rate in the control group (ca. $64 \%$ ) challenged orally with $10^{9}$ organisms. And the present results seem to suggest that there is a tendency that the smaller the challenge dose, the lower the morbidity rate and the longer the incubation period.

The rate of appearance of dysenteric cases in the group challenged intracecally with $10^{9}$ of $S$. Alexneri 2 a $(87.5 \%)$ was somewhat higher than that in the group challenged orally with the same dose (ca. $64 \%$ ). And it would be noted that the incubation period seemed to vary to fairly smaller degree in the former group than in the latter group or in the dysenteric cases previously reported (Honjo et al., 1964).

Bearing in mind not only the present results mentioned above but also the various results reported previously, for instances, (1) the oral administration with $10^{6}$ of $S$. flexneri 2a could not produce clear clinical changes characteristic of dysentery and $40 \%$ of monkeys challenged with $10^{9}$ bacilli by the oral route failed to develop dysentery (Takasaka et al., 1967) and (2) the large intestines were regarded as the primary site of multiplication of the orally administered Shigella bacilli even at the earlier stage of infection (Ogawa et al., 1966), the present authors should like to indicate the following two points relating to the mechanism of Shigella infection in cynomolgus monkeys. Firstly, it may be regarded as a prerequisite for Shigella infection in monkeys that a certain number of Shigella bacilli can reach the lumen of the large intestines and settle there for some time (insofar as the present experiment shows, the smallest dose required to establish infection in the large intestines may be around $10^{5}$ in number of bacilli). Secondly, the alimentary tract up to the small intestines may act as a rather unfavorable environment for passage of orally ingested Shigella bacilli into the large intestines although the factual conditions are not yet identified. Further studies would be required to scrutinize these two points.

Moreover, the fact that 1 of 8 monkeys challenged with $10^{9}$ organisms into the lumen of the cecum did not suffer from dysentery, in other words, the fact that a $100 \%$ attack rate was not gained even with the present method seems to suggest that one important factor determining the development of dysentery on the host side is present in the large intestine itself.

With regard to the establishment of Shigella infection following the direct injection 
of relatively small doses into the cecal lumen, it must also be taken into consideration that the stressful situation probably caused by the surgical operation of abdomen might result in a reduction of the non-specific resistance to Shigella infection.

\section{REFERENCES}

Honjo, S., Takasaka, M., Fujiwara, T., Nakagawa, M., Ando, K., Ogawa, H., TAKAHASHI, R. AND IMAIZUMI, K. (1964): Shigellosis in cynomolgus monkeys (Macaca irus). II. Experimental infection with Shigella flexneri $2 \mathrm{a}$ with special references to clinical and bacteriological findings. Japan. J. Med. Sci. Biol., 17, 307-319.

Honjo, S., Takasaka, M., Fujiwara, T., Kaneko, M., Imaizumi, K., Ogawa, H., Mise, K., NAKAMura, A. AND NAKAYA, R. (1967): Shigellosis in cynomolgus monkeys (Macaca irus). V. Resistance acquired by the repetition of experimental oral infection with Shigella flexneri 2a and fluctuation of serum agglutinin titer. Japan. J. Med. Sci. Biol., 20, 341348.

Miles, A. A., Misra, S. S. AND Irwin, J. (1938) : Estimation of bactericidal power of the blood. J. Hyg., 38, 732-749.

Ogawa, H., Takahashi, R., Honjo, S., Takasaka, M., Fujiwara, T., Ando, K., NAKAGAWA, M., Muto, T. AND ImAizUmi, K. (1964) : Shigellosis in cynomolgus monkeys (Macaca irus). III. Histopathological studies on natural and experimental shigellosis. Japan, J. Med. Sci. Biol., 17, 321-332.

Ogawa, H., Honjo, S., Takasaka, M., Fujiwara, T. And Imaizumi, K. (1966) : Shigellosis in cynomolgus monkeys (Macaca irus). IV. Bacteriological and histopathological observations on the earlier stage of experimental infection with Shigella flexneri 2a. Japan. J. Med. Sci. Biol., 19, 23-32.

Takasaka, M., Honjo, S., Fujiwara, T., Hagrwara, T., Ogawa, H. and Imaizumi, K. (1964): Shigellosis in cynomolgus monkeys (Macaca irus). I. Epidemiological surveys on Shigella infection rate. Japan. J. Med. Sci. Biol., 17, 259-265.

Takasaka, M., Honjo, S., Fujiwara, T., Imaizumi, K. and Ogawa, H. (1967) : Experimental infection with small doses of virulent Shigella flexneri 2a in cynomolgus monkeys (Macaca irus). Clinical and bacteriological observations. Japan. J. Med. Sci. Biol., 20, 195-198. 